\title{
The Establishment Clause, Secondary Religious Effects, and Humanistic Education
}

The Supreme Court decisions proscribing prayer ${ }^{1}$ and Bible reading ${ }^{2}$ in public schools provoked considerable public debate. That debate has continued, ${ }^{3}$ fueled in part by fear that the removal of those religious practices from public schools would hinder the moral development of school children. ${ }^{4}$ A number of different, avowedly nonreligious, moral education programs $s^{5}$ that purport to encourage and channel the moral development of the individual child have emerged in the wake of the prayer and Biblereading decisions. ${ }^{6}$ Although diverse in method, all of these programs, unlike more traditional forms of moral training, ${ }^{7}$ reflect the influence of an educational philosophy known as Humanistic Education.

The Humanistic Education movement, originally concerned primarily with counteracting the dehumanizing character of technocratic modern education, ${ }^{8}$ has evolved into a comprehensive social and moral philosophy"

1. Engel v. Vitale, 370 U.S. 421 (1962).

2. Abington School Dist. v. Schempp, 374 U.S. 203 (1963).

3. See N.Y. Times, Apr, 20,1980, 12 , at 3, col. 1 (many groups still fighting to put prayer back in public schools; between $10 \%$ and $30 \%$ of public schools still refuse to comply with prayer decisions).

4. See, e.g., N.Y. Times, Jan. 24, 1980, § 2, at 10, col. 5 (some proponents of prayer believe that "crime, vandalism, and drugs are all results of ruling prayer from the schools"); $c f . D$. BOLES, THE BIBLE, RELIGION, AND THE PUBLIC SCHOOLS 245-48 (1961) (proponents of Bible reading believe that its absence from public schools will lead to decline in moral standards).

5. See infra notes $48 \& 49$. This Note discusses some of the more widespread programs, including Values Clarification, Moral Development, sensitivity training, meditation, and fantasy guidance.

6. See Kirschenbaum, Recent Research in Values Clarification, in VALUES EDUCATION 71 (J. Meyer, B. Burnham, \& J. Chovlat eds. 1975) ("Values clarification approach' has gained widespread popularity throughout American education."); NEWSWEEK, June 2, 1980, at 58 (more than 6000 school systems have offered values education courses, and more than 300,000 classroom teachers have attended workshops to learn how to teach values education); N.Y. Times, Mar. 19, 1980, §3, at 1, col. 1 (values education still making inroads into American public elementary and secondary schools).

7. See Humanistic Education SOURCEboOK (D. Read \& S. Simon eds. 1975) (discussing philosophy of Humanistic Education) [hereinafter cited as D. READ \& S. SIMON]; E. SIMPSON \& M. GRAY, HUMANISTIC EDUCATION: AN INTERPRETATION (1976) (describing various Humanistic Education programs); R. VALETT, HUMANISTIC EDUCATION 1 (1977) (drawing distinction between traditional education and Humanistic Education); Alschuler, Humanistic Education, in D. READ \& SIMON, supra, at 62, 66 (describing Humanistic Education and how it differs from more traditional forms of moral training).

8. See C. PATtERSON, Humanistic Education 10-18 (1973); Miller, An Education for the Whole Person, in THE PERSON In Educntion 39, 41-42 (G. Schlosser ed. 1976).

9. See, e.g., E. SIMPSON \& M. GRAY, supra note 7, at 67 (Humanistic Education concerned with any subject matter that relates people to themselves, to each other, and to external environments, and encompasses many social and economic issues); Newmann, Social Action and Humanistic Education, in HUMANISTIC EDUCATION 67 (R. Weller ed. 1977) (Humanistic Education calls for comprehensive examination of social structures and systems of meaning). 
with specific implications for the design of curriculum, ${ }^{10}$ the relationship of teacher to student, ${ }^{11}$ and the role of education in society. ${ }^{12}$ Because systematic instruction in values and morality can act to advance or inhibit religious beliefs, ${ }^{13}$ the widespread introduction of Humanistic Education programs in public schools raises important issues under the establishment clause of the First Amendment. ${ }^{14}$ This Note takes a new look at the constitutional implications of government programs with secondary religious effects, using Humanistic Education in public schools as its main example. After examining present establishment clause doctrine in light of the historical purposes and values embodied in the clause, the Note argues that many forms of Humanistic Education, although not prohibited by present doctrine, pose a substantial threat to the core values of the establishment clause. The Note concludes that even though the establishment clause permits the state to pursue compelling governmental interests through some programs having secondary religious effects, current forms of Humanistic Education cannot be justified and should be eliminated.

\section{The Contours of Establishment Clause Doctrine}

The Supreme Court's early establishment clause decisions, drawing heavily upon aspects of the historic struggle for religious freedom in America, identified strict separation of church and state as the fundamental requirement of the establishment clause. ${ }^{15}$ Because a significant level of

10. See, e.g., THE PhILOSOPhY OF CURRICULUM (S. Hook, P. Kurtz, \& M. Todorovich eds. 1975) (essays discussing implications of Humanistic philosophy for design of curricula for social science, natural science, history, and general education); S. SIMON, L. HOWE, \& H. KIRSCHENBAUM, VAlUes ClARIFICATION: A HANDBOOK OF PRACTICAL STRATEGIES FOR TEACHERS AND STUDENTS (1972) (illustrating how to implement Values Clarification approach in public schools).

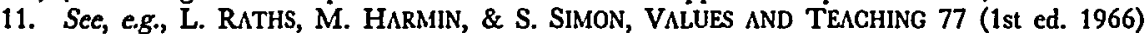
(discussing proper role of teacher in helping children form values); Rogers, The Interpersonal Relationship in the Facilitation of Learning, in HUMANIZING EDUCATION: THE PERSON IN THE PROCESS 1 (R. Leeper ed. 1967) (role of teacher is to help students teach themselves, not to transmit knowledge or values).

12. See, e.g., L. RATHS, M. HARMIN, \& S. SIMON, supra note 11, at 26 (although family plays limited role, educators should bear main burden for helping children define priorities and discover meaning out of confusion in modern society); Weinberg, The School, the Society, and the Individual, in HUMANISTIC FOUNDATIONS OF EDUCATION 71 (C. Weinberg ed. 1972) (educators must help shape moral and social outlook of children).

13. This Note deals primarily with certain explicit attempts by government to manipulate the moral orientation of children. Some commentators have argued, however, that public schools inevitably transmit and inculcate certain value judgments and are therefore constitutionally problematic whatever their official policies. See Arons \& Lawrence, The Manipulation of Consciousness: A First Amendment Critique of Schooling, 15 HARV. C.R.-C.L.L. REV. 309, 316-17 (1980). The balancing test proposed in this Note finds a middle ground between this extreme position and the deference shown in present doctrine. See infra p. 1223.

14. U.S. CONST. amend. I ("Congress shall make no law respecting an establishment of religion. ...")

15. See, e.g., Everson v. Board of Educ., 330 U.S. 1, 18 (1947) (establishment clause erects "high and impregnable wall" between church and state); McCollum v. Board of Educ., 333 U.S. 203, 21112 (1948) (reiterating Everson standard). 
contacts between church and state inhere in the structure of modern society, the application of the separation standard consistently proved problematic, and the Court eventually shifted to a set of more specific standards. Doctrinal missteps in the course of the Court's transition, however, have obscured the role of two closely related underlying purposes of the establishment clause: preserving freedom of religious choice, and maintaining the state's neutrality in private religious activities.

\section{A. The Legacy of the Separation-of-Church-and-State Standard}

The separation standard, as the Court originally formulated it, forbade almost all forms of government involvement with religion. The Court conceived the notion of religious "effect" as one way of expressing the absence of the required separation: contacts between church and state were deemed to have an unconstitutional religious effect. ${ }^{16}$

Because the early cases involved problems similar to those familiar to the framers of the First Amendment, ${ }^{17}$ the Court's initial reliance on the historical background of the establishment clause was understandable. The framers of the First Amendment undoubtedly viewed separation of church and state as a way of enforcing establishment clause values in the context of the extremely limited government with which they were familiar. The scale and diversity of government activities that characterize today's welfare state, however, have made contacts between church and state inevitable. Although that growth has not made the goals that the framers

16. Nithough the "effect" test was first formally announced as the constitutional standard in $\mathrm{Ab}$ ington School Dist. v. Schempp, 374 U.S. 203, 222 (1963), earlier cases had informally applied it. See McGowan v. Maryland, 366 U.S. 420, $442-43$ (1961) (noting that non-secular purpose and effect render enactment unconstitutional under establishment clause); Everson v. Board of Educ., 330 U.S. 1, 16-17 (1947) (discussing purpose and result of enaciment at issue). The role of "effect" in formulations of the separation standard carried over, however, to confuse the application of the effect test when it became the official instrument of the Court's establishment clause inquiry. Thus, the Court noted as recently as Board of Educ. v. Allen, 392 U.S. 236, 242-43 (1968), that "the constitutional standard is the separation of Church and State," but the test is "the purpose and primary effect of the enactment."

17. Opposition to the colonial practice of exacting public financial support for the politically dominant religion moved James Madison, one of the principal thinkers behind the establishment clause, to write his Memorial and Remonstrance Against Religious Assessment, quoted in Walz v. Tax Comm'n, 397 U.S. 664, 719 (1970) (Douglas, J., dissenting), and provoked Thomas Jefferson to join with him to press for and win an establishment prohibition in Virginia. See Everson v. Board of Educ., 330 U.S. 1, 11-12 (1947) (discussing history of Virginia Bill of Rights).

In light of this history, Everson, which involved a challenge to government payment of bus fares of children attending parochial schools, and McCollum v. Board of Educ., 333 U.S. 203 (1948), which involved a challenge to a released time program for religious instruction in public schools, both seemed to pose paradigmatic establishment clause issues. The Court responded in both cases by declaring that the establishment clause could not tolerate anything less than absolute separation of church and state, though it ultimately upheld the Everson statute. In later cases, the Court stressed that the lesson to be learned from history was that the union of church and state tends to degrade religion and provoke disrespect for governmental authority by focusing political division along religious lines, See, e.g., Engel v. Vitale, 370 U.S. 421,431 (1962). 
sought to embody in the First Amendment less important, it has left anachronistic and incomplete any system for applying the establishment clause that is centered on the specific approaches the Court associated with the framers. ${ }^{18}$

Indeed, the Court itself has long been troubled by a tension between keeping religion separate from government and excluding religion from the benefits of facially nonreligious governmental activity. There was no question, for example, that the state could provide fire and police protection to religious institutions. ${ }^{19}$ Similarly, though perhaps less clearly, providing free transportation to students in parochial as well as public schools seemed to be a legitimate governmental measure to secure the public welfare and safety. ${ }^{20}$ Yet by permitting such forms of aid to religion, the Court severely tested its strict-separation approach and exposed serious logical breaches in establishment clause doctrine. ${ }^{21}$

18. See L. TRIBE, AMERICAN CONSTITUTIONAL LAW 834 (1978) (movement from government of closely limited powers to affirmative state requires reevaluation of religion clauses; in affirmative state, religious tolerance may become "positive commitment that encourages the flourishing of conscience" rather than simply "negative principle"); Gianella, Religious Liberty, Nonestablishment, And Doctrinal Development (pt. 2), 81 HARV. L. REV. 513, 514-15 (1968) (because government is involved more extensively in structuring social order, treatment of religious groups has become fundamentally different question from that confronting framers of establishment clause); cf. Abington School Dist. v. Schempp, 374 U.S. 203, 235 (1963) (Brennan, J., concurring) ("too literal quest for the advice of the Founding Fathers upon [establishment clause] issues" is "misdirected").

19. See Everson v. Board of Educ., 330 U.S. 1, 17-18 (1947).

20. Id.

21. In the context of an extremely limited government, the principle of separation of church and state is workable and serves to protect religious freedom. As government grows in size and diversity of function, however, it inevitably assumes responsibilities that affect the welfare of religious groups. If, in this context, separation is interpreted to mean that government cannot institute measures to minimize or offset the deleterious impact of its programs on religious groups, the result is to inhibit religion. Professor Gianella uses the example of a hypothetical collectivist state that controls all resources to illustrate the tendency of the separation approach to inhibit religion as government expands. Because religious groups would be dependent upon the state merely to exist, the collectivist government would at a minimum have to provide them with property in order to avoid inhibiting religion. See Gianella, supra note 18 , at $522-23$. The separation standard would prohibit such salutary action. In fact, however, such action would actually contribute to, rather than detract from, the protection of establishment clause values by counterbalancing the inhibiting effect of governmental ownership of resources. The example of the hypothetical collectivist state shows that the correlation between separation of church and state and the protection of establishment clause values tends to decrease as the level of government influence over the social order increases.

Contemporary government does not, of course, exercise the dominance of the collectivist state, and the sort of restorative measures that would contribute to neutrality in the collectivist state would serve demonstrably to advance religion if effected by contemporary government. Nevertheless, contemporary government does exert influence over resources and activities whose control is of central concern to religious groups, making applicable the principle, though not the specific prescription, deducible from the collectivist state. Government regulation of radio and television air waves, for example, carries with it the responsibility to accommodate religious broadcasting. The elimination of religious programming would severely inhibit religion. Government regulations designed to ensure the survival of religious programming offset the inhibiting effect of government control of the air waves, and thus actually protect establishment clause values, even though such regulations offend the concept of separation of church and state. Similarly, government control over a public forum carries the obligation, if that forum is or must be opened to expression, to accommodate religious expression. Widmar v. Vincent, 102 S. Ct. 269 (1981). 
During the next twenty years, the Supreme Court developed an approach for testing the permissibility of governmental activities that requires it to assume, contrary to a rule of strict separation, that some government involvement with religion is consistent with the establishment clause. ${ }^{22}$ The Court currently applies a three-pronged test in establishment clause cases: if a challenged government program involves a nonsecular purpose, ${ }^{23}$ has a primary effect that advances or inhibits religion, ${ }^{24}$ or fosters an excessive entanglement between government and religion, ${ }^{25}$ the program is inpermissible. Unfortunately, the Court explained its move to the three-pronged test ${ }^{26}$ as an erosion of the separation standard, ${ }^{27}$ not

22. See Lemon v. Kurtzman, 403 U.S. 602, 614 (1971) (some involvement between government and religion is inevitable); Walz v. Tax Comm'n, 397 U.S. 664, 669-70 (1970) (establishment clause does not require rigid separation, but "benevolent neutrality" that permits religious exercise to exist without sponsorship or interference). The Court could have dealt with the pressure to limit the reach of the establishment clause by narrowing the definition of religion under the establishment clause. See infra note 40 .

23. The Court has expressly relied solely on an analysis of purpose in only two establishment clause cases in this century. See Stone v. Graham, 449 U.S. 39 (1980), reh'g denied, 449 U.S. 1104 (1981) (finding unconstitutional religious purpose in posting Ten Commandments on walls of public school classrooms); Epperson v. Arkansas, 393 U.S. 97, 103 (1968) (striking down law prohibiting teaching of evolution in public schools for having unconstitutional religious purpose). The Court typically defers to the State's proffered secular purpose, focusing instead on the effect of the program. See, e.g., Wolman v. Walter, 433 U.S. 229, 236 (1977) (usual problem is "effect" and "entanglement" analysis, not scrutiny of "purpose"); Lemon v. Kurtzman, 403 U.S. 602, 613 (1971).

The Court indirectly considered purpose in several cases when it analyzed the facial neutrality of legislative classification schemes. See, e.g., Walz v. Tax Comm'n, 397 U.S. 664, 680 (1970) (upholding constitutionality of tax exemption extended to religious, charitable, and nonprofit institutions); Board of Educ. v. Allen, 392 U.S. 236, 248-49 (1968) (upholding constitutionality of programs that lent secular textbooks to children in both private and public schools). Obviously, a narrow classification scheme that primarily benefits religious groups would suggest that the challenged legislation had a non-secular purpose. Cf. Committee for Public Educ. v. Nyquist, 413 U.S. 756, 794 (1973) (breadth of classification scheme relevant to political divisiveness test).

24. See infra note $28, \&$ p. 1204.

25. The entanglement prong of present doctrine has two distinct parts. One part of the entanglement test prohibits government activity that focuses political opinion along religious lines. See Meek v. Pittenger, 421 U.S. 349, 372 (1975) (establishment clause forbids government action that "creates a serious potential for divisive conflict over the issue of aid to religion-'entanglement in the broader sense of continuing political strife" "). The other part of the entanglement test is more specific, forbidding government action that places government in a monitoring capacity that requires close and continuous contact with a religious institution. Committee for Public Educ. v. Nyquist, 413 U.S. 756, 795-97 (1973) (establishment clause forbids entanglement of government with religion in sense of "a comprehensive, discriminating, and continuing state surveillance").

The adoption of the excessive entanglement test as a separate prong of establishment clause analysis in Lemon v. Kurtzman, 403 U.S. 602, 612-13 (1971), actually limited, rather than expanded, the role of the political neutrality value. The excessive entanglement prong, unlike the separation standard, has in practice largely limited concern for political neutrality to the context of institutional contact with religion. Compare Everson v. Board of Educ., 330 U.S. 1, 8-11 (1947) (discussing unconstitutionality of government action that creates entanglement in broader sense of continuing political strife over religious issues) with Wolman v. Walter, 433 U.S. 229, 244 (1977) (discussing only danger of administrative entanglement). Cf. Meek v. Pittenger, 421 U.S. 349, 373-79 (1975) (Brennan, J., concurring in part and dissenting in part) (arguing that Court has not given enough weight to broader aspect of entanglement posed by divisive political potential of programs).

26. See Lemon v. Kurtzman, 403 U.S. 602, 612-13 (1971).

27. Id. at 614 ("[T]he line of separation, far from being a 'wall,' is a blurred, indistinct, and variable barrier depending on all the circumstances of a particular relationship.") 
as a refinement, leaving the impression that it was reducing its commitment to underlying establishment clause values. Because the meaning of "religious effect" was bound up with the separation standard, the erosion of the standard led to the conclusion, now embodied in the three-prong test, that a prohibition of government programs with secondary effects advancing or inhibiting religion was, like complete separation, impractical. ${ }^{28}$

\section{B. The Fundamental Purposes of the Establishment Clause}

The Court's abandonment of the strict separation standard was appropriate, not because rigorous enforcement of establishment clause values is somehow impractical, but because the separation standard is a poor proxy for the clause's underlying values. The erosion of the separation standard should therefore be construed not as a devaluation of the establishment clause, but as an attempt by the Court to serve the clause's central purposes: the preservation of freedom of private religious choice and the maintenance of political neutrality.

The establishment clause, as the Supreme Court has long recognized, is intended to protect freedom of private religious choice. ${ }^{29}$ Its operation in prohibiting some governmental activities depends, not on any showing of actual government coercion of individual choice, ${ }^{30}$ but only on inducement

28. A prohibition of secondary religious effects does indeed appear impractical if the term effect is understood to refer to separation of church and state. Enforcing separation of church and state does not, however, always further constitutional ideals. The term religious effect is thus better applied to express the diminution in protection of establishment clause ideals that occurs when religion is advanced or inhibited. Used in this technical sense, the term religious effect would not apply to government action designed to mitigate the inhibiting effect of the dominance of governmental authority over activities directly affecting the welfare of religious groups. Such action contributes to the protection of establishment clause values by minimizing the adverse effect on religious groups of increased governmental intervention in the social order. $C f$. Zorach v. Clauson, 343 U..S. 306, 313-14 (1952) ("WW] the state encourages religious instruction or cooperates with religious authorities . . . it follows the best of our traditions."); Gianella, supra note 18, at 515 (private choice will be frustrated if government does not take religion into account in its allocation decisions). Similarly, the term religious effect would not encompass the effect of government action required by the free exercise clause. See infra note 30 .

By contrast, associating the term religious effect with separation of church and state results in the identification of the effect of innocuous government accommodation of religious interests as a religious effect and thereby creates an artificial pressure to shorten the reach of the effect test, as the Court has done by limiting the current test to "primary" effects. In essence, the Court has compensated for the lack of fit between underlying establishment clause values and its use of the term religious effect by extending blanket approval to secondary religious effects and artificially limiting the establishment clause prohibition to primary religious effects. This compromise, however, protects not only innocuous government action but also government action injurious to establishment clause values. Conforming the definition of religious effect to underlying establishment clause values eliminates the artificial pressure to truncate the reach of the effect test, and makes rigorous enforcement of establishment clause values feasible.

29. See Engel v. Vitale, 370 U.S. 421, $429-30$ (1962); Gianella, supra note 18, at 517.

30. Engel v. Vitale, 370 U.S. 421, 430-31 (1962). By contrast, the free exercise clause protects against coercion of choice. Id. Because coercion is an individual harm, government action that infringes free exercise clause values sometimes may be remedied by exempting the complaining individual from the program. See, e.g., Wisconsin v. Yoder, 406 U.S. 205 (1972) (partially exempting Old 
of choice. ${ }^{31}$ Moreover, since it is a government program's tendency to induce some choice, not actually to coerce it, that violates the establishment clause, the Court cannot preserve a challenged program from establishment-clause condemnation merely by exempting particular individuals from its reach. ${ }^{32}$ Government activity may induce private religious choice either by inhibiting or encouraging a particular religious choice. Advancement of religion occurs when government activity gives official sanction or support to the beliefs of a particular religion. ${ }^{33}$ Such activity may also have the effect of inhibiting belief in religions whose tenets conflict with the official view. Inhibition of private choice may also occur when, by its hostility to certain beliefs, government action makes a particular religious choice look less appealing. ${ }^{34}$

Closely related to the guarantee of religious voluntarism is the establishment clause's requirement that government avoid activity that tends to create significant political divisions over religious issues. ${ }^{35}$ Such activities

Order Amish from compulsory education law); Sherbert v. Verner, 374 U.S. 398 (1963) (exempting Seventh-Day $\Lambda$ dventist from unemployment benefit regulation requiring that she be available to work on Saturdays). By alleviating government-imposed burdens on religion, exemptions required by the free exercise clause merely restore government to a neutral position and thus do not run afoul of the establishment clause. See Wisconsin v. Yoder, 406 U.S. 205, 220-21 (1972) (protecting values promoted by right of free exercise not necessarily inconsistent with establishment clause); Merel, The Protection of Individual Choice: A Consistent Understanding of the First Amendment, 45 U. CHI. L. REV. 805, 823 (1978) (protection of particular religious exercise required by free exercise clause does not violate establishment clause values so long as similar exemptions not denied to other religious groups). Accommodation of free exercise interests can extend beyond the level of accommodation required by the free exercise clause. See Walz v. Tax Comm'n, 397 U.S. 664, 673 (1970) ("The limits of permissible state accommodation to religion are by no means co-extensive with the noninterference mandated by the Free Exercise Clause."); L. TRIBE, supra note 18, at 822 (actions even arguably compelled by free exercise clause should be permissible under establishment clause).

31. See Note, Toward a Uniform Valuation of the Religion Guarantees, 80 YALE L. J. 77, 85 (1970).

32. Abington School Dist. v. Schempp, 374 U.S. 203, 224-25 (1963) (exemption not a defense to claim of unconstitutionality under establishment clause); Engel v. Vitale, 370 U.S. 421, 430 (1962) (exempting students from having to recite prayer in public schools is unresponsive to constitutional problems of public school prayers).

33. $\Lambda$ bington School Dist. v. Schempp, 374 U.S. 203, 222 (1963) (establishment clause prohibits official government support for tenets of religion); Engel v. Vitale, 370 U.S. 421, 430-31 (1962) (establishment clause prevents government from placing its power and prestige behind religion).

34. See $\Lambda$ bington School Dist. v. Schempp, 374 U.S. 203, 225 (1963) (affirmative opposition or hostility to religion violates establishment clause); Everson v. Board of Educ., 330 U.S. 1, 15 (1947) (government action that inhibits religion by preventing particular religious choice violates establishment clause).

35. See Meek v. Pittenger, 421 U.S. 349, 372 (1975) (political division along religious lines was one of principal evils establishment clause was intended to protect against); Everson v. Board of Educ., 330 U.S. 1, 8-12 (1947) (reviewing dangers of political division along religious lines); $L$. TRIBE, supra note 18 , at 819 (establishment clause concerned with preventing sectarian differences from dividing body politic); Gianella, supra note 18, at 517 (establishment clause guards political neutrality as well as voluntarism).

Some commentators argue that the establishment clause, like the free exercise clause, can be reduced to a guarantee of freedom of private choice. See, e.g., Merel, supra note 30; Note, supra note 31 , at 98 n.102 (establishment clause consults no value other than private choice; political neutrality value is dependent on private choice value); Schwarz, No Imposition of Religion: The Establishment 
undermine the normal functioning of the political process. ${ }^{36}$ Indeed, it is an historical commonplace that political polarization along religious lines can threaten the viability of a political system. ${ }^{37}$

\section{Functional Aspects of Present Doctrine}

To achieve consistency and predictability of application, a constitutional system must have not only ideals, but some sort of principled structure capable of expressing the relationship between the ideals and the conflicts that impelled creation of the system. The strain of reducing constitutional ideals to an existential form inevitably forces revision of the structure and some adaptation of the ideals. The compromise reached by present doctrine takes the form of two functional limitations on the scope of the establishment clause.

The definition of religion plays a significant exclusionary role in current doctrine. ${ }^{38}$ Methodologically, the definition of religion could enter establishment clause analysis as a threshold issue or as a factor in the evaluation of the actual criteria of constitutionality. Treating the definition of religion as a threshold issue requires dividing the universe of beliefs advanced or inhibited by challenged governmental programs into two groups: religious and nonreligious. Programs advancing beliefs deemed to be religious pass the threshold and are then subjected to the actual criteria of constitutionality to determine, for example, whether they have a primary or secondary religious effect. Obversely, defining a system of belief as nonreligious automatically places the issue of its advancement beyond

Clause Value, 77 YALE L.J. 692, 710-12 (1968) (political strife criterion normally will argue both in favor of and against particular program, and, therefore, is not helpful guide). Some commentators also argue that the authors of the First Amendment intended only to protect religious choice, not to prevent political divisiveness over religious issues. See M. HOWE, THE GARDEN AND THE WILDERNESS 19 (1965). But see Freund, Public Aid to Parochial Schools, 82 HARV. L. REV. 1680, 1692 (1969) (framers of First Amendment considered political neutrality to be independent constitutional concern); Note, Government Neutrality And Separation Of Church And State: Tuition Tax Credits, 92 HARV. L. REV. 696, 699 (1979) (danger from political divisiveness exists apart from effect on private choice).

The current Supreme Court test embodies political neutrality as an independent concern, not merely as a derivative of the private choice value. See Meek v. Pittenger, 421 U.S. 349, 372 (1975); Lemon v. Kurtzman, 403 U.S. 602, 612-13 (1971). The old separation standard also placed considerable emphasis on political neutrality as an independent value. See, e.g., Engel v. Vitale, 370 U.S. 421, 430-35 (1962).

36. Lemon v. Kurtzman, 403 U.S. 602, 622 (1971) ("Ordinarily political debate and division, however vigorous or even partisan, are normal and healthy manifestations of our democratic system of government, but political division along religious lines was one of the principal evils against which the First Amendment was intended to protect. . . . The potential divisiveness of such conflict is a threat to the normal political process.")

37. Walz v. Tax Comm'n, 397 U.S. 664, 694 (1970) (Harlan, J., concurring) (government activity that encourages competition among religious sects for political supremacy can lead "to strife and frequently strain a political system to the breaking point").

38. See infra note 40 . 
the scope of the establishment clause. ${ }^{39}$

On the other hand, the definition of religion could be employed as a factor in evaluating the substantiality of a program's religious effect. Under this approach, the definition of religion would be used to assess the degree to which a system of beliefs advanced by challenged governmental action was religious. In turn, the degree to which a program was religious would be considered along with other factors, such as the directness with which the beliefs were advanced or inhibited, in determining whether a challenged program met the actual criteria of constitutionality. The lack of a clear constitutional basis for finally determining a definition of religion suggests that the dichotomous definition of religion required by a threshold analysis would be arbitrary. Nevertheless, current doctrine treats the definition of religion as a threshold issue, and thus implicity excludes from the scope of the establishment clause all systems of belief not deemed to be sufficiently religious. ${ }^{40}$

The limitation of the effect test in present doctrine to "primary" religious effects ${ }^{41}$ also performs an exclusionary function. Despite its significance as an exclusionary device, the distinction between primary and secondary effects is obscure. The distinction implicitly recognizes that most governmental programs whose constitutionality is questioned under the establishment clause will have both secular and religious components. Analyzing the way in which the secular and religious components of a program combine may thus shed light on the nature of the effect produced. ${ }^{42}$

\section{Humanistic Education and Establishment Clause Values}

The phenomenon of Humanistic Education in the public schools highlights the problem of identifying the proper scope of the establishment clause. Humanistic Education affects underlying establishment clause values, but does not fall plainly within the boundaries of the Supreme

39. See, e.g., L. TRIBE, supra note 18, at 828-29 (if Transcendental Meditation were considered nonreligious, its direct advancement in public schools would be constitutional).

40. The scope of the establishment clause can be manipulated by changing the definition of religion. A very broad definition of religion could significantly expand the scope of the establishment clause, thereby raising the same problems that the Court attempted to avoid in redesigning the actual criteria of unconstitutionality. See supra note 28 . For example, this assumption is implicit in Professor Tribe's assertion that a broad definition of religion under the establishment clause would prove unworkable. See L. TRIBE, supra note 18, at 827-28 (in age of affirmative state, less expansive notion of religion required for establishment clause purposes lest all "humane" government programs be deemed unconstitutional). Although the Court has not explicitly fashioned a definition of religion for establishment clause purposes, some commentators believe that the Court is moving toward a relatively narrow definition in order to avoid the problems suggested by Professor Tribe. See L. TRIBE, supra note 18, at 829 (Court employs narrower definition of religion for establishment clause purposes than for free exercise purposes); Note, Toward a Constitutional Definition of Religion, 91 HARV. L. REV. 1056, 1085-86 (1978) (arguing for express adoption of such bifurcated definition).

41. See infra note 82 .

42. See infra pp. 1212-16. 
Court's three-prong test.

\section{A. The Goals and Methods of Humanistic Education}

The general term, "Humanistic Education," applies to a variety of new educational programs that have largely eclipsed more traditional forms of formal moral discourse in public schools. ${ }^{43}$ Humanistic Education programs are endorsed by many leading educators $\mathrm{s}^{44}$ and receive financial support from the federal government and leading private foundations.$^{45}$ Educators favor Humanistic Education because it promises to meet the need in public school for moral instruction in a way that avoids the political and legal barriers to other forms of moral education. ${ }^{46}$ Instead of presenting children with a set of predetermined values, ${ }^{47}$ Humanistic Education attempts, by means of a controlled instructional environment, to teach children how to use its methodology to resolve the moral problems they will face in their lives.

Although all Humanistic Education programs deal with the social, psychological, and moral development of children, some emphasize cognitive development in these areas, ${ }^{48}$ while others emphasize affective or emo-

43. See E. SIMPSON \& M. GRAY, supra note 7, at viii, 8, 17, 59. In a small number of Humanistic Education programs, moral instruction suffuses every subject in the curriculum. See N.Y. Times, Mar. 4, 1980, § 3, at 1, col. 1 (trend is to attempt to apply moral education to every subject). These programs assume that, if moral instruction is to be meaningful and effective, it cannot be isolated and presented in an abstract sense, but must be related to each aspect of a student's life and thinking. More commonly, moral instruction is relegated to a discrete portion of the curriculum, in which specific programs play a major role.

44. See E. SIMPsON \& M. GRAY, supra note 7, at 16-17.

45. See id. at 59 (primary support for Humanistic Education has come from small number of influential individuals and private foundations); N.Y. Times, Mar. 4, 1980, $\S 3$, at 1, col. 1 (values of education movement became widespread when private groups and governmental agencies began to provide funding). Various state Humanistic Education Centers receive federal funding pursuant to 20 U.S.C. § 1119a (1976). See EDUCATION UPDATE, Fall 1979, at 2, col. 1.

46. See MORAL EDUCATION 3, 7-8 (D. Purpel \& K. Ryan eds. 1976) (discussing increasing demand on schools to inculcate morality); L. RATHS, M. HARMIN, \& S. SIMON, supra note 11, at 20 (schools searching for non-controversial way to teach morality).

47. The belief that absolutist positions are particularly controversial is in part responsible for Humanistic Education's assumption that presenting children with a set of predetermined values will, at best, be of little help and may even hinder children in their development. See L. R^THS, M. HARMIN, \& S. SIMON, supra note 11, at 44-45.

48. Values Clarification is one of the more widespread and influential of this type of Humanistic Education programs. See E. SIMPSON \& M. GRAY, supra note 7, at 8, 10-11. Values Clarification focuses on the process rather than substance of valuing; it assumes that no particular set of values is correct, in the abstract, for a given individual. See L. RATHS, M. HARMIN, \& S. SIMON, supra note 11 , at 28 ("Because life is different through time and space, we cannot be certain what experiences any one person will have. We therefore cannot be certain what values, what style of life, would be most suitable for any person.")

Values Education theorists define three processes that are essential to real valuing. First, persons must choose values after consideration of the consequences of alternative value choices and free of external inducement toward a particular choice. Second, they must prize and publicly affirm the chosen values. Third, they must act consistently upon those values. See id. at 28-30; S. SIMON, L. HowE, \& H. KIRSCHENBAUM, supra note 10, at 19 (setting forth practical strategies for classroom applica- 
tional development. ${ }^{49}$ The goals of the programs are accomplished through specific exercises. ${ }^{50}$ Typically, a teacher confronts students with a question, experience, or moral dilemma, ${ }^{51}$ and asks them to make a judgment in favor of some value, to state an opinion, or to express a feeling. ${ }^{52}$ The teacher then leads individual students in a programmed dialogue $e^{53}$

tion); S. Simon \& J. Clark, MORe VAlues Clarifichtion (1975) (examining use of Values Clarification in lives of teachers and how to apply it in groups).

Lawrence Kohlberg has developed a related, but distinct, program called Moral Development. Moral Development posits that exposure to moral conflict causes individuals to move upward through three levels, which include six invariantly sequenced stages, of moral development. The first stage is Preconventional Moral Reasoning, in which physical consequences define "goodness" and reciprocity guides moral behavior. The second stage is Conventional Moral Reasoning, in which societal approval is equated with goodness. The third stage is Postconventional Reasoning, in which morality is based on social contract, but the individual's conscience operates independently of the system. See Kohlberg, A Cognitive-Developmental Approach to Moral Education, in READINGS IN MORAL EDUCATION 36 (P. Scharf ed. 1978) [book hereinafter cites as P. SCHARF].

49. Various programs, broadly denominated sensitivity training, focus on facilitating the emotional growth of the individual. See Black, Encounter Groups ". . . May Loom as a Potential Source of Salvation," in D. READ \& S. SIMON, supra note 7 at 188; Davis, Helfert, \& Shapiro, Let's Be an Ice Cream Machine! Creative Dramatics, in D. READ \& S. SIMON, supra note 7, at 439; Krafft \& Howe, Guidelines for Sensitivity Training in Your School, in D. READ \& S. SIMON, supra note 7, at 321. Sensitivity training programs use role playing, discussion, and other forms of social interaction to help the individual become sensitive to the needs of others. In the process, the individual is meant to develop a heightened sense of self-awareness and self-acceptance. Typically, the programs confront students with a person or simulated experience and then encourage them to verbalize their feelings concerning the confrontation. See, e.g., E. SIMPSON \& M. GRAY, supra note 7, at 88-91 (describing widely used technique known as The Trumpet March).

Another program under the rubric of sensitivity training is fantasy guidance. Students are asked to fantasize about a variety of topics, including taking a trip to the moon in a spaceship, engaging in a sexual experience, and being an ice cube. See, e.g., R. JONES, FANTASY AND FEELING IN EDUCATION (1968); E. SIMPSON \& M. GRAY, supra note 7, at 82; id. at 88. In one Humanistic approach to sex education for students in junior high and high school, "students are asked to lie on their backs in a circle, with arms interlocked, and share their sexual fantasies one at a time within the confines of a dark room. It is a threatening situation for some, but they generally get into the sharing mood quickly." Read, Developing Sexual Awareness: A Humanistic Approach, in D. READ \& S. SIMON, supra note 7 , at 417 .

50. See, e.g., S. Simon, L. HOWE, \& H. KirSChenbaUm, supra note 10; E. Simpson \& M. GRAY, supra note 7 , at $77-91$.

51. In Values Clarification questionnaires, questions dealing with moral issues are interspersed with questions that are not even arguably moral in nature. See, e.g., S. SIMON, L. HOWE, \& H. KIRSCHENBAUM, supra note 10, at $41,50,51,52,53$ ("How many of you . . . would encourage legal abortion for an unwed daughter . . . read Playboy magazine . . . would be upset if organized religion disappeared ... watch your weight . . think that parents should teach their children to masturbate. . . watch the Super Bowl every year"). Some commentators have argued that Values Clarification confuses moral and non-moral issues. See Graham, Moral Education: A Child's Right to a Just Community, 6 ElEMENTARY SCHOOL GUIDANCE AND COUNSELING 300 (1975). Moral Development is one of the few programs that considers only moral issues. See R. HERSCH, J. MILLER, \& G. FIELD. ING, MODELS OF MORAL EDUCATION 119 (1980); Kohlberg, supra note 48, at 43.

52. See S. SiMON, L. HOWE, \& H. KIRSCHENBAUM, supra note 10 (discussing specific exercises for Values Clarification); E. SIMPSON \& M. GRAY, supra note 7, at 77-91; Beyer, Conducting Moral Discussions in the Classroom, in P. SCHARF, supra note 48, at 62-75.

53. See, e.g., E. SIMPSON \& M. GRAY, supra note 7, at 88-91. Humanistic Education is essentially heuristic, relying upon self-reflection as the source of moral development. Id. at 7-9; sec P. VITZ, PSYCHOLOGY AS RELIGION 79-82 (1977) (discussing religious dimensions of self-reffection methodology). This approach is based on the belief that people are innately good and that they will, if prodded, develop in a positive direction. See Kohlberg, The Claim to Moral Adequacy of a Highest Stage of Moral Development, 70 J. PHIL. 630 (1973); Lee, Christian Religious Education and Moral 
designed to help them understand the ramifications or intellectual sufficiency of their responses. ${ }^{54}$ Humanistic Education theorists assume that this process will stimulate moral and personal growth. ${ }^{55}$

\section{B. The Impact of Humanistic Education on Religious Freedom}

Various forms of Humanistic Education conflict sharply with certain religious faiths. ${ }^{56}$ Humanistic Education programs generally assume that the "whole" person consists of the mind, emotions, personality, and body, ${ }^{57}$ that the emotions and personality can be developed through a process of internal clarification facilitated by classroom procedures such as responding to and discussing questionnaires, ${ }^{58}$ meditating, ${ }^{59}$ and discussing fantasies; ${ }^{60}$ that there are few, if any, ${ }^{61}$ inherently right and wrong val-

Development, in Moral Development, MORAl EduCATION, AND KoHLBERg (B. Munsey ed. 1980) (tenet that each person is basically good and has fundamental orientation toward higher levels of moral development is center of Kohlberg's approach) [hereinafter cites as B. MUNSEY].

54. Cognitive approaches test the sufficiency of the student's position or opinion in light of certain principles. Values Clarification examines, among other things, whether the student freely developed the response, whether he or she has considered the consequences of following the response through other situations, and whether he or she is proud of the response. See, e.g., E. SIMPSON \& M. GRAY, supra note 7, at 88-91. Numerous models for implementing the Moral Development approach have been suggested, see, e.g., Beyer, supra note 52, at 69 (applying five types of "probe" questions to ten major issues relevant to most moral dilemmas), but each model emphasizes a "content-free" dialectic designed to stimulate the reasoning of the individual child. See Rosenzweig, Kohlberg in the Classroom: Moral Education Models, in B. MUNSEY, supra note 53, at 359-60. The dialectic in affective approaches is designed to help the student verbalize more fully his or her feelings and to make the student feel comfortable with those feelings. See E. SIMPSON \& M. GRAY, supra note 7, at 88-91.

55. See, e.g., E. SIMPSON \& M. GRAY, supra note 7, at 9 (Moral Development rests on premise that exposure to moral conflict will cause individual to move upward through moral stages). Some educators criticize this premise. See Lockwood, A Critical View of Values Clarification, in D. PURPEL \& K. RYAN, supra note 46, at 164-65 (advocates of Values Clarification do not answer such "fundamental questions as: assuming Adolph Hitler, Charles Manson, Martin Luther King, and Albert Schweitzer held values which met the seven criteria, are their values equally valid, praiseworthy, and/ or good?").

56. This conflict has been discussed by several authors. See, e.g., T. LAHAYE, BATTLE FOR THE MIND (1980) (Humanistic Education fundamentally at odds with Biblical Christianity); O. MCGRAW, SECULAR HUMANISM AND THE SCHOOLS: THE ISSUE WHOSE TIME HAS COME (1976) (Humanistic Education embodies religious beliefs hostile to traditional religions).

57. The focus on the "whole" person is central to Humanistic Education. See C. SCHLOSSER, supra note 8, at 10-12; E. SIMPSON \& M. GRAY, supra note 7, at 64-65; Mosher, Education In Human Development in R. WELLER, supra note 9, at 172. Most Humanistic Educators distinguish between education that merely develops the intellect and education that integrates intellectual with emotional and physical development, often termed "confluent" education. See, e.g., Brown, What is "Confuent Education"? in D. READ \& S. SIMON, supra note 7, at 50.

In attempting to deal with the whole person, Humanistic Education inevitably collides with establishment clause values. If Humanistic Education actually deals with the spiritual or religious aspect of the "whole" person, it unconstitutionally intrudes into religious areas. See infra note 77. On the other hand, if Humanistic Education denies that there is a spiritual or religious aspect of the individual, it proclaims a view that is hostile to religion. See infra note 65.

58. See, e.g., S. SIMON, L. HOWE, \& H. KIRSCHENBAUM, supra note 10, at 13-22.

59. See, e.g., Alschuler, supra note 7 , at 63 .

60. See, e.g., R. JONES, supra note 49. Sensitivity training, role playing, and psycho-drama focus on the expression of feeling as a therapeutic device. See supra note 49. The tone of these programs' assumptions about the nature of man and morality are distinctly religious. See P. VITZ, supra note 53, 
ues, ${ }^{62}$ and that man is innately good..$^{63}$ In contrast, several major religious faiths $^{64}$ teach that man has a spirit in addition to personality and emotions, or is primarily a spiritual being; ${ }^{65}$ that clarification of values should be guided by an external standard; ${ }^{66}$ that there are right and wrong values

at $28-33,79-82$.

61. Some values educators have recently conceded that a normative approach to certain values such as stealing and murder may be appropriate. See N.Y. Times, Mar. 4, 1980, \$ 3, at 1, col. 1.

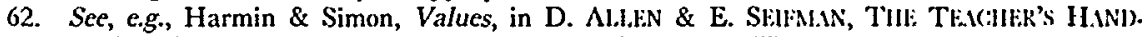
BOOK 294 (1971) (values are "relative, personal, and situational"); S. SMION, L. Howl:, \& H. KIRS(IIENB.IUM, supra note 10, at 15-17 (discussing why "moralizing" or "direct inculcation" is deficient as means of moral education). Most Humanistic Education programs reject absolute values and the idea that human purposes and goals could be determined by God or any other external standard. See E. SIMIPSON \& M. GRAY, supra note 7, at 3 ("Actively antihumanistic education occurs when teachers believe that human purposes and goals are determined from without, from external authorities, whether groups, individuals, or personalized all-powerful forces, rather than from within the individual.")

Kohlberg's Moral Development theory does, however, posit the existence of such principles as justice and equality, and makes normative judgments about the structure of moral reasoning, as evinced by his six-tier ranking of different structures of such reasoning. Yet Kohlberg's approach rejects the validity of extrinsic, transcendent, or independent moral values; in Kohlberg's theory, morality is a purely rational and therefore internal and dependent construct. See, e.g., Kohlberg, Stages of Mforal Development as a Basis for Moral Education, in MOR.1. El)l(:.TT1ON (C. Beck ed. 1971) (form of moral judgment is universal, but content is relative); $c f$. Chazan, Jewish Education and Moral Development, in B. MuNsti, supra note 53, at 298, 315-16 (in ignoring need for substantive moral values, Kohlberg's approach conflicts with modern as well as classical Jewish education, which argue for specific moral system derived from revealed truth). The theory thus retreats to a relativistic posture when it is confronted with moral questions whose resolution from a purely rational perspective is problematic, even assuming a priori acceptance of principles such as justice and equality.

63. Man's innate dignity, goodness, and worth is a unifying principle of Humanistic Education. See, e.g., E. SIMPSON \& M. GRAY, supra note 7, at 4 (antihumanistic education occurs when man is perceived as instinctively evil or prone to evil). The belief in the innate goodness of man, in turn, is used to justify the assumption that exposure to moral conflict will propel the individual in a positive direction and that expression of self, whether through sensitivity training, encounter groups, or fantasy guidance, will promote moral and emotional growth.

64. In order to assess the positions of religious groups on the issues discussed in this Note, the notewriter contacted 41 major religious organizations. Interviews were conducted by telephone with leaders or spokespersons for 38 of these groups. Each group was also sent a questionnaire in order to give it an opportunity to confirm and clarify its position in writing. The groups were also asked to provide any pertinent doctrinal statements they had published. Notes 65-68 infra contain representative citations to interviews, letters, and statements, as well as general conclusions, of the investigation. $\Lambda$ full report of the survey, including doctrinal statements submitted, letters or responses to the questionnaires, and summaries of the telephone interviews, is on file with the Yale Law Journal.

65. See, e.g., Letter from General Secretary, General Council of the Assemblies of God (Jan. 1981) (man's spiritual nature is most important aspect of his being); Letter from Chuck Smith, Pastor, Calvary Chapel (March 1981) (man's spirit allows him to communicate with God, and "puts him a whole dimension above the animals," but until he is "born of the Spirit," John 3:6, 7, he cannot understand spiritual things, I Corinthians 2:14); Interview with Keith Mitchell, Director of Int'] Missions of Church of Christ (Mar. 1981) (man has a spirit, although it cannot be neatly distinguished from rest of his being).

66. Many religious groups believe that moral decisions should be made by reference to sources of revealed truth such as the Bible. See Letter from Dr. Charles Wright, Dean of the $\Lambda$ postolic Faith Bible Institute, The Church of the Lord Jesus Christ of the Apostolic Faith (Mar. 23, 1981) (Bible, revealed by Holy Spirit, is source of all moral truth); Interview with Charles Dunahoo, Coordinator Christian Education, Presbyterian Church in America (Mar. 1981) (Bible is explicit on most moral questions); Letter from Dr. J.A.O. Preus, President, The Lutheran Church Missouri Synod (Mar. 1981) ("moral principles are set forth in the Scriptures, the Word of God"; answers to moral dilemmas should "be based on Scripture and not merely on the situation or some relative or contextual 
that are transcendental and absolute rather than situational and relative, ${ }^{67}$ and that man is by nature sinful..$^{68}$

At the same time, the premises of Humanistic Education coincide with the beliefs of the nontheistic philosophical movement usually called Secular Humanism. ${ }^{69}$ In its most common forms, Secular Humanism assumes the irrelevance of supernatural phenomena, regards man as a natural object, asserts man's innate goodness and potential to achieve self-realization through reason, and views man as the sole and ultimate judge of his own morality. ${ }^{70}$ By many definitions, Secular Humanism is a religion, ${ }^{71}$ and

development").

67. See THIS WE BELIEve (undated doctrinal statement of International Church of the Foursquare Gospel) (Bible is standard for daily living); SOUTHERN BAPTIST CONVENTION, THE BAPTIST FAITH AND MESSACiE 7 (1963) (Bible is supreme standard for all human conduct); Letter from Thomas McDill, President, Evangelical Free Church of America (Mar. 19, 1981) ("God has set forth moral principles for man that reflect His Holiness"; these principles are "absolute," but "must be applied with love, grace, and compassion"); Interview with Rabbi Gillman, Dean of Rabbinical School, Jewish Theological Seminary (Mar. 1981) (classical Jewish thinking, illustrative of most Orthodox and many Conservative Jews, holds that Scripture, as interpreted by rabbinical tradition, is source of absolute moral truth).

68. Many religious groups believe that, although made in the image of God, man fell and is thus now sinful by nature. See SOUTHERN BAPTIST CONVENTION, BAPTIST FAITH AND MESSAGE (1963); Interview with Director, Watchtower News Service (Mar. 1981) (Jehovah's Witnesses); Interview with Dr. Albert Meyer, Director, Mennonite Board of Education (Mar. 1981).

69. "Humanism" refers to a number of movements and beliefs, both historical and contemporary. See, e.g., J. HUXLEY, THE HUMANIST FRAME 13-48 (discussing type of psycho-social evolutionary Humanism); A Humanist Manifesto I, 6 NEw HUMANIST (May-June 1933) (setting forth doctrine of Religious Humanism). "Secular Humanism" likewise describes no single organized movement, but is generally associated with tenets similar to, though not usually as comprehensive as, those summarized in Humanist Manifesto II, 33 HumanisT 4 (Sept.-Oct. 1973). See A SECULAR HUMaNisTiC DeCLARATION 7-29 (P. Kurtz ed. 1980); Whitehead \& Conlan, The Establishment of the Religion of Secular Humanism and Its First Amendment Implications, 10 TEX. TECH. L. REV. 1, 29-54 (1978); infra note 70 . To the extent that Humanism is presently an organized movement with a set of shared beliefs, it tends to take the form, if not always the label, of Secular Humanism. See Whitehead \& Conlan, supra. At least two Humanistic educators have made the connection between Secular Humanism and Humanistic Education explicit. See D. BRUBAKER \& J. ZAHORIC, TOWARD MORE HUMANISTIC INSTRUCTION 4-9 (discussing eleven premises of Humanistic Education that roughly track definition of Secular Humanism in Humanist Manifesto II, 33 HUMANIST 4-9 (Sept.-Oct. 1973)). On the other hand, although Humanistic Educators often refer to Humanism, it is not always clear that they mean Secular Humanism. See, e.g., O'Kane, The Fourth Face of Humanism, in HUMANISTIC EDUCATION 331 (R. Weller ed. 1977) (discussing idea of defining Humanism as constricting; noting religious aspects of some forms of Humanism).

70. The Humanist Manifesto II, 33 HUMANIST 4-9 (Sept.-Oct. 1973), contains 17 major statements of belief, including assertions that God, religion, and the supernatural are at best irrelevant; that specific religious beliefs, including belief in heaven or hell, or any form of life after death, the existence of a separable human "soul," and the creation of man by a direct act of God, are dangerous and represent obstacles to human progress; that moral values are wholly relative and situational; that meaning is a function of happiness in "the here and now," that the scientific method and reason are the best tools by which to achieve fulfillment as individuals and communities; that no form of sexual conduct short of "unbridled promiscuity" is evil; and that individuals should have the right to abortion, divorce, and birth control. The preface to the Manifesto asserts that "humanists still believe that traditional theism, especially faith in the prayer-hearing God, assumed to love and care for persons, is an unproved and outmoded faith," and that "salvationism . . . is harmful." Id. at 4. The Manifesto concludes that Humanism is "a growing, living faith." See id. at 9. The proponents of Secular Humanism do not unanimously subscribe to all the propositions asserted in Humanist Manifesto II. See, e.g., 33 HUMANIST 7-10 (Nov.-Dec. 1973); 33 HumaNIST 4 (Sept.-Oct. 1973). In practice, the views 
the courts have in fact, at least for certain purposes, characterized it as a religion. ${ }^{72}$

Because Humanistic Education fundamentally conflicts with certain religions and at least arguably promotes others, it will tend to affect private religious choice and to engender political division along religious lines. The threat to private choice is particularly serious in the public school context because pre-college students may lack the capacity to reflect maturely on the programs' messages ${ }^{73}$ or to resist peer pressure, ${ }^{74}$ and because the schools themselves are inherently authoritarian. ${ }^{75}$ The threat to political neutrality is already emerging: religious groups have begun to organize politically against Humanistic Education in the public schools. ${ }^{76}$

of Secular Humanists tend to coalesce around a somewhat narrower set of beliefs, such as the relativity of morals, the centrality and dignity of man, and the sufficiency of reason.

71. The system of beliefs set forth in Humanist Manifesto II, supra note 70, is easily characterized as religious. The Manifesto is the statement of an organized group supporting a system of beliefs that addresses a comprehensive range of ultimate concerns, including specific views on life after death, meaning, morality, man's role in the Universe, the existence of the supernatural, and the existence of a separable soul in man. Cf. infra p. 1215 (discussing factors courts generally employ in determining whether a system of beliefs is religious); Whitehead \& Conlan, supra note 69, at 54 (reaching conclusion that Humanist Manifesto constitutes religious creed).

In its more common forms, Secular Humanism is not as dogmatic or comprehensive as the version articulated in the Humanist Manifesto. See supra note 70 . Nevertheless, many scholars consider the movement as a whole to be religious. See, e.g., D. EHRENFELd, THE ARROGANCE OF HUMANISM 4 (1978).

72. See, e.g., United States v. Seeger, 380 U.S. 163 (1965) (including Humanistic and nontheistic beliefs as religions in construing meaning of religion for purposes of conscientious objection exemptions to Selective Service statute); Torcaso v. Watkins, 367 U.S. 488, 495 n.11 (1961) ("Among religions in this country which do not teach what would generally be considered a belief in the existence of God are Buddhism, Taoism, Ethical Culture, Secular Humanism and others."); Malnak v. Yogi, 592 F.2d 197, 200 (3d Cir. 1979) (Adams, J., concurring) (arguing that establishment clause encompasses nontheistic religions such as Secular Humanism). Humanism is consistently accepted as a religion for purposes of the free exercise clause. See Washington Ethical Soc'y v. District of Columbia, 249 F.2d 127, 129 (D.C. Cir. 1957); Fellowship of Humanity v. Alameda County, 153 Cal. App. 2d 673, 315 P.2d 394 (1957).

73. See R. GOLdMAN, Religious THinking From GHILDHOOD TO AdolesCENCE 239 (1964); K. HYDE, RELIGIOUS LEARNING IN ADOLESCENCE 104 (1965).

74. Cf. Abington School Dist. v. Schempp, 374 U.S. 203, 290-91 (1963) (Brennan, J., concurring) (young children disinclined to step out of line or to flout "peer-group norms"); McCollum v. Board of Educ., 333 U.S. 203, 227 (1948) (Frankfurter, J., concurring) (nonconformity not outstanding characteristic of school children). Peer pressure plays a role in Values Clarification programs. See Stewart, Problems and Contradictions of Values Clarification, in D. PURPEL \& K. RYAN, supra note 46, at 139-40 (peer pressure combines with Values Clarification strategies to coerce students to the "mean").

75. See L. TRIBE, supra note 8 , at 825 (public schools carry authority of state and are inherently inculcative); cf. J. MILL, ON LIBERTY 190-91 (1859) (government-run education "is a mere contrivance for moulding people to be exactly like one another: and as the mould in which it casts them is that which pleases the predominant power in the government, . . . it establishes a despotism over the mind").

76. See N.Y. Times, Aug. 19, 1980, $\S 4$, at 17, col. 1 (evangelicals reacting with alarm to what they believe is takeover of public schools by Secular Humanism). Publications in religious journals reflect the intensity of this alarm. See, e.g., Hill, Parents Sleep While Humanism Destroys Souls of Youth, VOICE OF FREEDOM June 1980, at 87 ("The ultimate objective of Humanism is to train the consciences of our youth so that they recognize no need for God and Christ. . . ."); McMaster, Our Public Schools, CHRISTIAN LIFE MAGAZINE, June 1980, at 32 (preface) ("Humanism is such a pleas- 
Despite this threat to the underlying values of the establishment clause, most forms of Humanistic Education inhibit religion only indirectly ${ }^{77}$ and promote beliefs that are only arguably religious. ${ }^{78}$ Because the establishment clause forbids only programs with "primary" religious effects" and may not reach programs that advance systems of belief that are only arguably religious, ${ }^{80}$ these forms of Humanistic Education may fall outside the scope of present doctrine. This gap between the establishment clause's underlying values and the substantive reach of present doctrine requires a reexamination of the relevance of "secondary" religious effects for establishment clause analysis.

\section{Secondary Effects and the Establishment Clause}

The Court's formal focus upon primary effects evolved, as a refinement of the earlier strict separation standard, partly to reconcile the establishment clause with certain forms of government support for religion. Because the current primary effects test has serious functional limitations, however, the Court's next step should be to find a new and more worka-

ant-sounding word that it disarms most people. But unless this trend in education is rooted out of our public schools, the future of our nation is imperiled.")

77. See Committee for Pub. Educ. v. Nyquist, 413 U.S. 756, 775-76 (1973) (indirect religious effects not unconstitutional). Some Humanistic Education practices do have the primary effect of inhibiting religion. For example, some of the questions included in certain Values Clarification questionnaires are specifically slanted to cast doubt upon specific religious beliefs and institutions. See, e.g., S. SIMON, L. HOWE, \& H. KIRSCHENBAUM, supra note 10, at 41, 43, 140 ("How many of you . . . would choose to die and go to heaven if it meant playing a harp all day long? . . . are getting anything out of [Sunday school or religion class]?") To the extent that Values Clarification or other Humanistic Education programs directly intrude into patently religious or spiritual areas, they will have an unconstitutional primary effect. $C$. Reed v. Van Hoven, 237 F. Supp. 48, 56 (S.D. Mich. 1965) (ordering that no projects be assigned on religious or irreligious topics such as "Why I believe or disbelieve in religious devotions"); Moskowitz, The Making of the Moral Child: Legal Impliçations of Values Education, 6 PEPPERDINE L. REV. 105, 126 (1978) (specific substantive statements about religion in Values Clarification materials make its presentation in public schools unconstitutional under primary effect test).

There is also a new cluster of programs that purport to be Humanistic, but actually involve various forms of spiritualism and eastern religion. Programs dealing in transpersonal psychology, for example, actually involve spiritual psychology. See P. VITZ, supra note 52, at 13, 14; C. TART, TRANSPERSONAL PSYCHOLOGIES (1978). For a description of such programs, see Canfield \& Klimek, Education in the New Age, NEW AGE J., Feb. 1978, at 13 ("[S]tudents are asked to review their life in reverse ... until they come to the time before they were born. Here they meet a guardian spirit whom they ask 'What is my life purpose?'. . . Many teachers have begun to work with mandalas. ... [A]dditional emphases in the transpersonal dimension are using nature as a teacher and aligning and communicating with the other kingdoms such as the elemental and devic realms, . . . working with children's psyche capacities such as secing auras, working with astrological charts to provide students with what each most needs. . . .") These programs' explicit involvement with eastern religions makes them unconstitutional under the Court's current primary effect test. Cf. Malnak v. Yogi, 592 F.2d 197 (3d Cir. 1979) (striking down Transcendental Meditation program).

78. See supra notes 69-72.

79. See Committee for Pub. Educ. v. Nyquist, 413 U.S. 756, 775-76, 783 n.39 (1973) (indirect effects have never been thought sufficient to invalidate government action).

80. See L. TRIBE, suipra note 18, at 827-31 (arguably nonreligious groups should be excluded from definition of religion under establishment clause); Note, supra note 40, at 1085. 
ble approach involving scrutiny of secondary effects as well.

\section{A. A Typology of Secondary Effects}

The essence of all secondary religious effects ${ }^{81}$ is that they accompany a primary secular effect. ${ }^{82}$ The Supreme Court's explicit focus upon primary effects, however, has prevented it from considering other, less unitary, characteristics of secondary effects. These distinguishing characteristics can be used to identify four models of secondary religious effects, which this Note denominates subordinate, ancillary, indirect, and diffuse. The resulting typology reveals that present doctrine, under the guise of both the primary effect test and the entanglement test, already reaches some types of secondary effects, but fails to reach other, equally signifcant, types. The typology further serves to suggest why such discrimination between different types of secondary effects frustrates the enforcement of establishment clause values.

\section{Subordinate Religious Effects}

Government activity may have secondary religious effects if it has both a direct secular impact and a direct, but less significant, religious impact. Despite its directness, the religious message of a program may be so overshadowed by the greater prominence of a direct secular message that its effect becomes relatively insubstantial. A typical public holiday pageant occurring during the Christmas season and including a nativity scene exemplifies such a subordinate secondary effect. ${ }^{83}$ Although such pageants

81. Secondary religious effects should be distinguished from incidental religious effects of the sort that arise in free exercise cases. For example, a state law requiring a photograph on an individual's driver license would not offend the establishment clause even though an individual could properly claim a free exercise exemption from the law if it interfered with his or her beliefs. Bureau of Motor Vehicles v. Pentecostal House of Prayer, Inc., 380 N.E.2d 1225 (Ind. 1978). In such cases, the religious "effect" arises not from the religiousness of the law, but from its incidental conflict with the individual's belief system. See L. TRIBE, supra note 18, at 831 (free exercise claims examined in terms of role that beliefs assume in individual's life). Because such effects involve an individualistic evil, they do not pose a serious threat to establishment clause values.

82. The Supreme Court has denied that its primary effect test calls for a distinction between primary and secondary effects. See Committee for Pub. Educ. v. Nyquist, 413 U.S. 756, 783 n.39 ("Our cases simply do not support the notion that a law found to have a 'primary' effect to promote some legitimate end under the state's police power is immune from further examination to ascertain whether it also has a direct and immediate effect of advancing religion.") The Court seems to be arguing that the true import of the "primary" limitation is rather a distinction between substantial and insubstantial religious effects. Although the Court's construction of the primary effect test signals a move toward a stronger establishment clause standard, the Court has wholly ignored the need to give some content in analytical terms to its distinction. This Note argues that the Court, in striking down only some types of programs with secondary religious effects, has applied an idiosyncratic understanding of the meaning of "substantial" religious effect.

83. Such a pageant was upheld under the establishment clause in Allen v. Morton, 495 F.2d 65 (D.C. Cir. 1973). The pageant, conceived as a tourist attraction, featured the National Christmas Tree, a reindeer pen, a stage for the presentation of music and cultural events, a yule log fire, and a 
have a direct religious message, the religious effect is significantly subordinated to a predominant secular message of entertainment and nonsectarian celebration.$^{84}$ Not all programs that have distinct secular and religious implications will, however, have only a secondary religious effect: state-organized Bible reading and prayer in public schools, for example, have both direct religious and direct secular effects. ${ }^{85}$ The relative importance of the religious effects of such activities make them "primary" by any reasonable standard..$^{86}$

\section{Ancillary Religious Effects}

Wholly secular government programs whose implementation requires close and continuous interaction with religious institutions have the potential, due to their obtrusive presence, to "chill" religious choice. ${ }^{87}$ For example, loaning public school teachers to private religious schools to teach nonideological subjects such as mathematics and history has, in theory, no religious effect because it aids only the school's secular function. ${ }^{88}$ Yet, if

creche containing a nativity scene. Id. at 78-79 (Leventhal, J., concurring).

84. See id. at 72 (religion was not substantial aspect of challenged program). But see id. at 87-88 (Leventhal, J., concurring) (arguing that pageant had impermissible primary religious effect). The Allen opinion is particularly significant because it followed the Supreme Court's decision in Committee for Pub. Educ. v. Nyquist, 413 U.S. 756 (1973), which implicitly expanded the scope of the primary effect test. See infra pp. 1217-18. The circuit court believed that even under the expanded test, this type of effect was constitutional. See Note, A Workable Definition of the Establishment Clause: Allen v. Morton Raises New Questions, 62 GEO. L.J. 1461 (1974).

85. Sce Abington School Dist. v. Schempp, 374 U.S. 203, 210, 223-24 (1963). The secular purposes proffered by the state were "the promotion of moral values, the contradiction to the materialistic trends of our times, the perpetuation of our institutions, and the teaching of literature." Id.

86. Id.

87. See Lemon v. Kurtzman, 403 U.S. 602,620 (1971) (discussing potential of continuous government contact to intrude on religion); Board of Educ. v. Allen, 392 U.S. 236, 255-56, 265-66 (1968) (Douglas, J., dissenting) (continuing surveillance of choices of textbooks made by private schools in order to assure loan of only "secular" textbooks will tend to erode religious choice as well as provoke political division).

88. The notion that government can constitutionally aid the secular function of a private religious school was first explicitly developed in Board of Educ. v. Allen, 392 U.S. 236, 247-48 (1968) (upholding loan of secular textbooks to religious school because Court could not, absent proof, assume that such aid furthered anything but schools' secular function). The Allen doctrine was significantly modified by later cases that, in effect, shifted the burden of proof to the government to show that aid to a religious school advanced only the schools' secular function. See, e.g., Meek v. Pittenger, 421 U.S. 349, 391-93 (1975) (Rehnquist, J., dissenting) (arguing that Court has unfairly shifted burden to government to show that aid advances only secular function of school); Committee for Pub. Educ. v. Nyquist, 413 U.S. 756, 775-76 (1973) (discussing factors that affect whether aid is indisputably marked off for support of school's secular function). The doctrine is still employed, however, to justify certain types of nonideological aid to private religious schools, such as providing lunches, transportation, and public health facilities. See Meek v. Pittenger, 421 U.S. 349, 364-65 (1975). But see Wolman v. Walter, 433 U.S. 229, 249-50 (1977) (nonideological aid may further religious mission of religious school if school is pervasively sectarian).

The secular function doctrine suffers from the fact that aid that advances the secular function of a religious school inevitably frees funds to advance the school's religious mission. This phenomenon can best be understood as an indirect religious effect that exists in addition to the ancillary effect arising from the monitoring required to ensure that aid primarily advances only a school's secular function. 
constant government surveillance is necessary to ensure that the public school teachers do not succumb to institutional pressure to inculcate religion, the presence of the government accompanying the aid will tend to stifle religious choice. ${ }^{89}$ Such aid, though wholly secular in nature, has an ancillary secondary religious effect.

\section{Indirect Religious Effects}

Government programs may have a secondary religious effect if they only indirectly inhibit or advance religion. Humanistic Education provides a clear example of an indirect secondary religious effect. ${ }^{90}$ Although $\mathrm{Hu}-$ manistic Education is grounded upon a set of beliefs that clearly conflict with the tenets of major religious faiths, most Humanistic Education programs do not explicitly teach these beliefs; $;{ }^{91}$ the methodology and content of the programs are derived from clear ideological premises, but students are not directly exposed to those premises. Nevertheless, if the programs succeed, many students will acquire a moral orientation that is inconsistent with some religions and coincidental with others. That orientation may, in turn, make some students more likely to accept, and others more likely to reject, particular religious beliefs. To the extent that the programs influence religious beliefs, however, that effect is an indirect result of the admittedly secular pursuit of encouraging students in their moral development. ${ }^{92}$

See infra p. 1214 (discussing indirect effects); cf. Committee for Pub. Educ. v. Nyquist, 413 U.S. 756, 775-76 (1973) (conceding that aid to secular function of religious school will indirectly advance religious function, but arguing that such indirect religious effects have never been thought unconstitutional).

89. See Meek v. Pittenger, 421 U.S. 349, 369-72 (1975) (invalidating loan of public school personnel to private religious school to perform speech and hearing tests and to engage in guidance counseling because such aid required unconstitutional level of monitoring to assure that loaned personnel maintained strictly nonideological postures).

90. Another example is the advancement of the religious function of a private religious school resulting from government aid to its wholly secular function. See supra note 88 . Exclusive instruction in the theory of evolution in public schools provides yet another example of the indirect religious effect. The theory of evolution both indirectly inhibits some religions and indirectly advances others. See Note, Freedom of Religion and Science Instruction in Public Schools, 87 YALE L.J. 515, 523-26 (1978) (teaching evolution in public schools undermines belief in many major religions).

91. But see supra note 77 (discussing some Humanistic Education programs that have primary religious effect).

92. The premise of modern public education is that "secular education can be isolated from all religious teaching." Abington School Dist. v. Schempp, 374 U.S. 203, 218 (1963) (quoting Everson v. Board of Educ., 330 U.S. 1, 23-24 (1947) (Jackson, J., dissenting)). Yet moral development in some form has been implicit in the structure of American education since the inception of the public school system. CF. Goss v. Lopez, 419 U.S. 565, 593 (1975) (Powell, J., dissenting) ("In an age when the home and church play a diminishing role in shaping the character and value judgments of the young, a heavier responsibility falls upon the schools.") The courts appear to assume that the government has a secular interest in the character and moral development of its people and, that, therefore, morality can be secular. Cf. Brown v. Board of Educ., 347 U.S. 483, 493 (1954) (education "is a principal instrument in awakening the child to cultural values"). As a philosophical matter, the notion of a secular morality is in dispute. See, e.g., B. MITCHELL, MORALITY: RELIGIOUS AND SECULAR (1980) 


\section{Diffuse Religious Effects}

Government activity may produce a secondary religious effect when its message, although direct, has no clear religious component or is only arguably religious. Just as the directness and prominence of a religious message may determine whether its effect is secondary, the degree to which the message is clearly religious will also bear on the substantiality of its religious effect. Government activity whose religious meaning lurks within an inseparable secular meaning will produce a more diffuse and therefore less substantial religious effect than activity that is clearly religious, if only because an arguably religious effect is also an arguably secular effect.

The form of Secular Humanism promoted by Humanistic Education illustrates one kind of arguably religious program. Although definitions of religion are problematic, courts and commentators have tended to label systems of belief as "religious" in terms of one or more of three characteristics: addressing ultimate concerns, espousing a comprehensive view of life, and possessing certain external indicia, such as ritual, symbols, and organizational structures. ${ }^{93}$ To the extent that a government program is not identified with one or more of these characteristics, ${ }^{94}$ courts will find it less obviously religious. Humanistic Education programs ${ }^{95}$ do touch on many ultimate concerns, ${ }^{96}$ but the programs do not promote their method

(discussing relationship between morality and religion and conflicting views on that relationship). Whatever the philosophical merits of the notion, however, its acceptance appears to be necessary in order to reconcile the public school system as presently conceived with the establishment clause. See, e.g., Arons \& Lawrence, supra note 13. At the same time, there obviously must be limits on what the state can do in the name of morality. The somewhat amorphous notion of secular morality was born out of this tension.

As a legal rather than a philosophical concept, however, secular morality may have more validity than first appears. If the notion is explained in terms of private choice, it may be a useful way of describing moral views as to which there is a social consensus. Certainly, the connection between morality and religion will be more significant in the public school context when the moral views presented diverge from the beliefs of the children or their parents. On the other hand, when moral views converge, despite different underlying religious beliefs, it seems more credible to distinguish between morality and religion. Of course, if the derivation of moral views is put at issue, the conflict is unavoidable. This analysis leads to two conclusions about the nature of secular morality for constitutional purposes. First, since consensus is less likely as the range of moral views discussed increases, discussion of morality in public schools should be restricted to certain core moral issues. Second, discussion of the source of morality should be avoided because it shifts the focus from an area of consensus to the underlying religious conflict. Cf. infra at p. 1224 (applying these conclusions to analysis of Humanistic Education).

93. See, e.g., Malnak v. Yogi, 592 F. 2d 197, 207-10 (3d Cir. 1979) (Adams, J., concurring); Note, supra note 40 , at $1086-88$.

94. The weight accorded to any one characteristic varies with the context. Normally, the absence or presence of any one of the three characteristics by itself would not be dispositive of whether a program is religious. See Malnak v. Yogi, 592 F. 2d 197, 209 (3d Cir. 1979) (Adams, J., concurring).

95. See supra notes $48 \& 49$.

96. See supra pp. 1207-08. The basic issues of right and wrong, and the role of man in the universe, are two of the three ultimate concerns mentioned by Judge Adams in his concurrence in Malnak v. Yogi, 592 F.2d 197, 209 (3d Cir. 1979). Judge Adams also argued that of the three characteristics, the presence of ultimate concerns normally offers the most compelling evidence for 
for moral development as a substitute for, or to the exclusion of, religious life or a relationship with God. ${ }^{97}$ In addition, although the philosophical movement of Secular Humanism does possess a limited institutional structure, the form of Secular Humanism promoted by Humanistic Education programs is not easily identified with any organizational structure, ritual, or symbolism..$^{98}$ Secular Humanism is, on balance, arguably nonreligious, and might be excluded by a narrow definition of religion; yet because Humanistic Education programs attempt fundamentally to alter the moral orientation of children, they thus are also at least arguably religious.9

\section{B. The Relation Between Establishment Clause Tests and the Defini- tion of Religion: Implications of the Typology of Secondary Effects}

By suggesting that the extent to which a program is religious bears on the substantiality of its religious effects, this Note departs from previous establishment clause analysis. Prior analysis distinguishes between ques-

finding a system of belief religious. See id. at 208 .

97. To the extent that Humanistic Education programs address the relevance of religious life, belief in God, or other religious issues, they are clearly religious. See supra note 77 (discussing such programs).

98. Secular Humanism is supported by the Fellowship of Religious Humanists and the Ethical Culture movement. See C. CHAMBERS, THE SIECUS CIRCLE (1977). Some Secular Humanists also participate in deliberative bodies that issue doctrinal statements. See, e.g., N.Y. Times, Oct. 15, 1980, $\S$ 1, at 18, col. 1 (Secular Humanist group attacks fundamentalist Christian groups). The Humanist, published by the American Humanist Association, functions as a clearinghouse for Humanist dialogue.

Other surface signs of religion such as ritual are definitely lacking in Secular Humanism. Indeed, the notion of ritual is objectionable to many Humanists. But see D. EHRENFELD, supra note 71, at 4 (Humanism has forms analogous to ritual).

99. Laws regarding abortion, homosexuality, and polygamy illustrate another kind of arguably religious program. Each of these laws relates to a specific ultimate concern and is based on underlying beliefs identifiable with specific organized religions. See, e.g., N.Y. Times, Aug. $19,1980, \S 4$, at 17, col. 4 (evangelical Christians unite in opposition to abortion). The Supreme Court has denied that such laws raise establishment clause or free exercise clause concerns. See, e.g., Harris v. McRae, 448 U.S. 297 (1980), reh'g denied, 448 U.S. 917 (1980) (1980) (denying that funding restriction on abortion payments under Medicaid raised any establishment clause issues); United States v. Reynolds, 98 U.S. 145 (1878) (upholding statutory prohibition of polygamy against free exercise clause challenge with caveat that "laws are made for a government of actions and while they cannot interfere with mere religious belief and opinions, they can with practices"). But see L. TRIBE, supra note 18, at 838, $839 \mathrm{n} .17$ (if moral value underlying prohibition or requirement is closely linked to competing religious tradition, then serious establishment clause issues raised).

All laws with a moral component could be considered arguably religious, but the attenuation in most instances is so pronounced that attaching the label makes little sense. Laws against stealing, for example, have a well-recognized instrumental as well as "ultimate" aim, and are not distinctly identified with particular sectarian traditions. The distinction between arguably religious enactments and substantially secular laws is analogous to the distinction between a secular morality, see note 92 supra, and moral issues that inevitably implicate religious beliefs. Ultimately, both distinctions rest upon the existence of some consensus among religious groups as to certain core or operating moral values. Without a substantial element of consensus among religious groups on the basic moral structure of society, religious conflict in the political arena may be unavoidable. See generally Rushdoony, The State as an Establishment of Religion, in FREEDOM AND EDUCATION: PIERCE V. SOCIETY OF SISTERS RECONSIDERED (D. Kommers \& M. Wahoske eds. 1980) (religious beliefs underlie positions on abortion, homosexuality, and polygamy issues). 
tions relating to the definition of religion and arguments relating to the actual criteria of unconstitutionality such as the effects test. ${ }^{100}$

The typology of secondary religious effects illustrates that treating the definition of religion as a threshold issue is fundamentally mistaken. The degree to which a program is clearly religious is merely one of several factors that describe the relation between the secular and the religious elements of a program and therefore determine the substantiality of a program's religious effect. The degree to which a program is clearly religious will affect the strength of its impact on private choice in the same sense that the directness and prominence of a religious message will affect the strength of its influence on private choice.

In practice, the distinction between the various types of secondary effects may blur. Though in a given case any one of the factors set out in the Note's typology could determine the substantiality of an effect, none is, as a principled matter, qualitatively more significant than the others. Certainly none is talismanic.

\section{The Implicit Role of Secondary Effects in Present Doctrine}

When the actual practice of courts in establishment clause cases is evaluated in light of the typology of secondary effects, it becomes readily apparent that, despite present doctrine's formal emphasis on "primary" effects, the courts have in fact struck down government aid to religious institutions that had secondary effects. ${ }^{101}$ Even if the purpose and primary

100. See, e.g., L. TRIBE, supra note 18, at 826, 834; Boyan, Defining Religion in Operational and Institutional Terms, 116 U. PA. L. REV. 479 (1968); Merel, supra note 30; Comment, Defining Religion: Of God, the Constitution and the D.A.R., 32 U. CHI. L. REV. 533 (1965); Note, supra note 31. Some of the literature does recognize that manipulating the definition of religion affects the reach of the three-prong test, or that expanding or contracting the test affects the meaningfulness of the definition of religion under the establishment clause. See Merel, supra note 30, at 821-22 (tension between free exercise clause and establishment clause can be reduced either by manipulating definition of religion or by constricting reach of substantive doctrine); Note, supra note 40 , at 1084,1088 n.144 (recognizing substantive effect of manipulating definition of religion). None of the literature has suggested, however, that these two lines of establishment clause inquiry might be defined in terms of each other.

101. In Lemon v. Kurtzman, 403 U.S. 602, 613-14 (1971), for example, the Court invalidated, among other things, a salary supplement paid to teachers in private religious schools who taught wholly secular subjects. Because monitoring was necessary to ensure that "subsidized teachers do not inculcate religion," the Court held that the program fostered an excessive entanglement between government and religion. Id. at 619 . The Court conceded that the purpose of the plan-aiding the religious schools in their secular function of teaching nonideological subjects such as math and history-was secular and declined to decide whether the program had a primary effect that offended the establishment clause.

Similarly, in Meek v. Pittenger, 421 U.S. 349, $367-72$ (1975), the Court relied solely on the entanglement prong in invalidating a government program that supplied, among other things, guidance counselors to religious schools. Refusing to find that such aid had an impermissible primary effect, the Court concluded that the "potential for political entanglement together with the administrative entanglement which would be necessary to ensure that auxiliary-services personnel remain strictly neutral" necessitated invalidation of the program. Id. at 372 . The distinction drawn by the Court between 
effect of a program are secular, the Gourt will, under the entanglement test, weigh the potential obtrusiveness of the government's interaction with the religious institution against the secular justification for the program. ${ }^{102}$ Similarly, in discussing the distinction between primary and secondary religious effects, the Court recently suggested that subordinate religious effects were unconstitutional. ${ }^{103}$ The Court stated that government programs with direct religious effects were unconstitutional, regardless of whether such effects were less substantial than the secular effects of the programs. ${ }^{104}$ Significantly, many commentators consider the school-aid cases to be unconvincing and doctrinally confusing. ${ }^{105}$ While the Court strikes down programs involving some types of secondary effects, it has failed to strike down programs entailing indirect religious effects or diffuse religious effects. ${ }^{106}$

\section{Toward anew Doctrine of Secondary Effects}

Though distinctions may be drawn between primary and secondary effects, they are not significant enough to justify ignoring the threat to establishment clause values posed by secondary effects. In predicating the constitutionality of government programs upon such distinctions, current doctrine gives them artificial significance and validity. Proscription of secondary effects in some contexts would respect those distinctions without according them undue significance.

\section{A. The Possibility of An Absolute Prohibition of Secondary Effects}

The example of Humanistic Education demonstrates that secondary as well as primary religious effects can threaten the underlying values protected by the establishment clause. ${ }^{107}$ That the threat operates on an indi-

political and administrative entanglement suggests that what the Court calls administrative entanglement actually comprehends infringement of the private choice value.

102. Meek v. Pittenger, 421 U.S. 349, 367-72 (1975); cf. Committee for Pub. Educ. v. Nyquist, 413 U.S. 756, 795 (1973) (political divisiveness of program must be weighed against secular purposes).

103. Committee for Pub. Educ. v. Nyquist, 413 U.S. 756, 783 n.39 (1973).

104. Id. ("Our cases simply do not support the notion that a law found to have a 'primary' effect to promote some legitimate end under the State's police power is immune from further examination to ascertain whether it also has the direct and immediate effect of advancing religion.")

105. See, e.g., Gaffney, Postscript: Meek, Wolman, And The "Fear of Imaginable But Totally Implausible Evils" In The Funding Of Non-Public Education, in FREEDOM AND EDUCATION: PIERCE v. SOCIETY OF SISTERS RECONSIDERED 79 (D. Kommens \& M. Wahoske eds. 1980) (distinctions drawn in school-aid cases make little sense as coherent constitutional doctrine and less sense as clear guidelines for educators and policy-makers). The Court itself has divided on most of these cases. See, e.g., Meek v. Pittenger, 421 U.S. 349 (1975).

106. Cf. L. TRIBE, supra note 18, at 840 (in place of distinction between primary and secondary effects, Court recently has substituted distinction between "direct and immediate" and "indirect and incidental," thus expanding reach of effect test).

107. See supra pp. 1213-16. 
rect level does not eliminate it. Subtle persuasion of school children may be more pernicious than outright indoctrination. ${ }^{108}$ Similarly, a religious effect does not lose its potential to compromise personal choice or foster political discord merely because it is subordinate, ancillary, or diffuse.

Many commentators have argued that, even if the concept of secondary religious effects has internal validity, an expanded establishment clause standard would be unworkable or oppressive. ${ }^{109}$ They contend that, since secondary religious effects by definition accompany primary secular effects, prohibiting government programs with secondary religious effects would necessarily frustrate legitimate secular interests. In some cases, for example, prohibiting secondary effects would frustrate the government's legitimate interest in aiding the secular function of private religious schools. ${ }^{10}$ Such a prohibition would also ultimately challenge the validity of the public school system, whose very existence tends to inhibit religions that believe that education cannot be divorced from religion. ${ }^{111}$ If the idea of a secondary effect includes the effects of arguably religious programs, a prohibition of secondary effects would be far-ranging indeed, possibly even invalidating social welfare programs. ${ }^{112}$

The fear that a broad definition of religion under the establishment clause would lead to such results has led numerous commentators to conclude that a narrower, more traditional, definition of religion is necessary to prevent the clause from overreaching its purposes. ${ }^{113}$ The same problems do not afflict the free exercise clause, because it can accommodate such beliefs through exemptions; ${ }^{114}$ the establishment clause, because it protects the social dimensions of private choice, cannot. ${ }^{115} \mathrm{~A}$ thoroughgo-

108. Sce K. HYvE, supra note 73, at 98-104 (critical attitude during adolescence leads to rejection of beliefs overtly urged upon students).

109. See, e.g., L. TRIBE, supra note 18, at 827-28; Merel, supra note 30, at 821; Note, supra note 40, at 1084. The fear of a broad establishment clause standard may be overstated. See Malnak v. Yogi, 592 F.2d 197, 212-13 (3d Cir. 1979) (Adams, J., concurring) (comprehensiveness criterion in definition of religion prevents establishment clause from becoming unworkable and from invalidating legitimate secular programs such as social welfare activity).

110. See supra note 88 (discussing secondary religious effect of aid to secular function of religious school).

111. See Merel, supra note 28, at 821; Little, Pierce and the Religion Clauses: Some Reflections, in FREEDOM $\Lambda$ ND EDUCATION: PIERCE V. SOCIETY OF SISTERS RECONSIDERED 69, 72 (D. Kommers \& M. Wahoske eds. 1980); cf. Freund, Public Aid to Parochial Schools, 82 HARv. L. REv. 1680, 1685 (1969) (if public schools supported secular religion, First Amendment would require their abolition).

112. See L. TRIBE, supra note 18, at 827-28; Note, supra note 40, at 1084. But see Malnak v. Yogi, 592 F.2d 197, 212-13 (3d Cir. 1979) (Adams, J., concurring) (comprehensiveness component of broad definition of religion would prevent this extreme result).

113. See L. TRIBE, supra note 18, at 828-29 (establishment clause should exclude any arguably nonreligious group); Note, supra note 40, at 1085 (arguing for dual definition); cf. Malnak v. Yogi, 592 F.2d 197, 211 n.48 (3d Cir. 1979) (Adams, J., concurring) (noting that substantial majority of commentators favor dual definition of religion for free exercise and establishment clauses).

114. See supra note 30 (discussing exemptions under free exercise doctrine).

115. Abington School Dist. v. Schempp, 374 U.S. 203, 221, 224-25 (1963). 
ing prohibition of secondary effects would therefore be impractical. Although current doctrine accords too much weight to the distinctions between primary and secondary effects, an absolute prohibition of secondary effects would thus accord them too little weight.

\section{B. A Balancing Test for Secondary Effects}

Although an effective establishment clause standard must reach secondary effects to fulfill the purposes of the constitutional guarantee, that reach need not be absolute. Outside its core, the establishment clause could be enforced through a balancing test similar to that used to enforce other First Amendment guarantees. ${ }^{116}$

The development of a balancing approach under the free speech clause is particularly instructive. Just as establishment clause decisions reveal a reluctance to prohibit government action whose primary effect is secular in order to alleviate a merely secondary burden on religion, some decisions under the free speech clause have involved a refusal to remove incidental burdens on speech resulting from government regulation of conduct. ${ }^{117}$ The courts in the latter group of cases feared that absolute protection of conduct under the free speech clause would, like a prohibition of secondary effects under the establishment clause, unduly restrict government action. ${ }^{118}$ To avoid this prospect, some early free speech cases simply refused to concede that certain conduct contained a speech element; ${ }^{19}$ the courts eventually recognized, however, that protecting the speech element

116. Justice Brennan advocated the use of a least restrictive means test in his concurrence to Abington School Dist. v. Schempp, 374 U.S. 203, 231 (1963) (Brennan, J., concurring) (arguing that establishment clause enjoins those involvements of religious with secular institutions that use religious means to serve governmental ends where secular means would suffice). He reiterated this test in concurrences to several later cases. See, e.g., Walz v. Tax Comm'n, 397 U.S. 664, 680 (1970) (Brennan, J., concurring); Lemon v. Kurtzman, 403 U.S. 602, 643 (1971) (Brennan, J., concurring). He now seems satisfied, however, by the expansion of the scope of the primary effects test in Committee for Pub. Educ. v. Nyquist, 413 U.S. 756, 783 n.39 (1973) (declaring that government programs with primary secular effects not immune from further scrutiny to see if such programs also have "substantial" and "direct" religious effects). See Meek v. Pittenger, 421 U.S. 349, 373 n.1 (1975) (Brennan, J., concurring) (referring to Nyquist formulation).

117. See, e.g., Cox v. Louisiana, 379 U.S. 559, 562-64 (1965) (distinguishing valid regulation of conduct from invalid regulation of "pure" forms of expression); Giboney v. Empire, 336 U.S. 490, 498 (1949) (speech as integral part of conduct not protected by Constitution). Before the speechconduct distinction was fully articulated, however, the Court protected some forms of conduct under the free speech clause. See, e.g., Thornhill v. Alabama, 310 U.S. 88, 101 (1940) (picketing protected by First $\Lambda$ mendment). Without pressing the analogy too far, cases like Thornhill can be usefully compared to early establishment clause cases, which also claimed to rely upon a broad and absolute standard. See supra pp. 1197-99 (discussing separation standard).

118. See L. TRibl, supra note 18, at 601 (early free speech decisions unwilling to concede that free speech clause had any relevance to political assassinations, bank robberies, or other violent modes of expression).

119. See Kalven, Upon Rereading Mr. Justice Black On The First Amendment, 14 U.C.L.A. L. REV. 428, 449-50 (1967) (Justice Black's absolutist view of free speech clause forced him to articulate distinction between speech and conduct so as to avoid rendering clause unworkable). 
in conduct did not always represent a serious threat to governmental interests. ${ }^{120}$

Current free speech doctrine protects the speech element in conduct without unduly restricting government by balancing the governmental interest in regulating the conduct against the incidental burden on speech. ${ }^{12 t}$ Government regulation of conduct is invalid under that balancing approach unless it furthers a substantial or compelling interest. ${ }^{122}$ Moreover, even if the governmental interest is substantial, the current test will permit an incidental burden on speech only to the extent necessary to further the government's substantial interest. ${ }^{123}$ The government must, therefore, tailor its means to fit its interest in a way that affirmatively avoids burdening free speech. ${ }^{124}$

The free exercise clause also employs a balancing test to reconcile legitimate government interests with the protection of religious liberty. ${ }^{125}$ Under the free exercise clause, once a claimant demonstrates infringement of a religious interest, the burden shifts to the state to prove that the program is justified by a compelling interest. ${ }^{126}$ If the government meets this burden, it must then also prove that the challenged program was the least burdensome means of fulfilling that interest. ${ }^{27}$

Applied to establishment clause problems, the balancing test would allow a government program that has the secondary effect of advancing or inhibiting religion to stand only if the government could demonstrate that its program was the least burdensome means of achieving a secular goal whose value was compelling, relative to the degree of infringement of religious freedom. The test would thus require the government to articulate its secular interest and to justify the fit between its chosen means and its interest, but would let the government pursue a program that could not avoid affecting religion if the primary secular effect of the program were sufficiently important. By making explicit the weighing process that now proceeds, if at all, under the guise of applying an absolute standard, the

120. See, e.g., Erznoznik v. City of Jacksonville, 422 U.S. 205, 209 (1975) (recognizing that protected speech may take different and even "ingenious" forms).

121. See O'Brien v. United States, 391 U.S. 367, 376-77 (1968).

122. Id. at 376. Government can, however, regulate expressive conduct subject to only minimal scrutiny if it falls within one of four narrowly drawn categories: speech or expressive conduct that is directed to incite immediate violence and is likely to incite such action, that is defamatory, that invades privacy, or that is obscene.

123. See O'Brien v. United States, 391 U.S. 367, 376-77 (1968).

124. For example, if a law is not narrow enough to reflect a close fit between the state's means and its interests, the Court may not recognize the legitimacy of the state's interest. See, e.g., Street v. New York, 394 U.S. 576, 592 (1969) (statute applied to proscribe "fighting words" invalidated because not narrowly drawn to punish only such words).

125. See Sherbert v. Verner, 374 U.S. 398, 406 (1963) (interest of state must be balanced against free exercise right at issue).

126. Id.

127. Id. at 407 . 
test would also help to ensure that establishment clause cases were decided consistently. ${ }^{128}$ The application of the test to one set of facts would provide a standard against which to compare future balancing questions.

An explicit weighing process is preferable to the assumption implicit in current doctrine that the benefits of proscribing certain types of secondary effects are never significant when compared to the sacrifice of governmental interests that such a proscription would entail. This assumption would be justifiable only if the government's interest in the primary secular effects of its programs were always substantial relative to the secondary religious effects of those programs, and the value of alleviating secondary religious infringement were never worth the cost of forcing government to use a less burdensome alternative to accomplish its interest.

The balancing test would supplant such speculation with a more sensitive approach. The test would, for example, largely eliminate the need for an artificially narrow definition of religion under the establishment clause by simply requiring that government not use an arguably religious means to a secular end if a secular means would suffice. ${ }^{129}$ Similarly, the test would often prevent other types of secondary religious effects by requiring that government not use a means with an indirect, subordinate, or ancillary impact on religion, if a means without such effects could fulfill the government's interest. By qualifying in a principled way the expansiveness of the secondary effects proscription, the test would obviate the type of discrimination among secondary effects in which the Court has engaged in recent cases.

\section{The Balancing Test Applied to Humanistic Education}

Most forms of Humanistic Education have the primary secular effect of inculcating morality. ${ }^{130}$ Because Humanistic Education also has secondary religious effects, its constitutionality will depend on whether the government's interest in inculcating morality in public schools is compelling when weighed against the programs' secondary religious infringement, and on whether there are less burdensome means of inculcating morality.

128. The balancing approach would also make explicit the reality that religious freedom is sometimes sacrificed to compelling governmental ends. Current doctrine sidesteps this problem by defining the asserted freedom away. But, when religious freedom is at stake, hiding substantive moves in definitional gambits is a dangerous practice, of. United States v. Ballard, 322 U.S. 78, 92 (1944) Uackson, J., dissenting), especially since the distinction between secondary and primary religious effects is largely a question of judgment rather than a difference in kind. The balancing approach not only shows greater respect for religious freedom in a substantive sense, but raises the court's awareness of it even when a compelling secular interest requires its subordination.

129. Because the test permits government activity with a compelling interest, adding arguably religious groups to the list of establishment clause religions would not make the clause unworkable.

130. See supra note 77 (discussing forms of Humanistic Education with primary religious effects); supra note 92 (discussing notion of secular morality). 


\section{Weighing Humanistic Education's Interest Against Its Religious Effects}

Humanistic Education's secondary religious effects, promoting Secular Humanism and inhibiting traditional religions, are serious. But instruction in morality will inevitably tend to conflict and to coincide with various religious beliefs to some extent, no matter how apparently nonreligious the instruction may be. ${ }^{131}$ It is arguable that such instruction thus necessarily results in secondary religious infringement. Yet the view that morality can be secular has, if not complete theoretical support, wide appeal ${ }^{132}$ and some basis in precedent. ${ }^{133}$

Moreover, it seems clear that government has a compelling interest in the character of its citizens. Indeed, it would be difficult to deny the legitimacy of this interest in light of the traditions of various forms of moral instruction in public schools. ${ }^{134}$ In sum, it appears that the government's compelling interest in preserving some form of moral instruction in public schools outweighs the burden of secondary religious infringement.

\section{Means Analysis}

Although the ends of Humanistic Education would not violate a balancing test under the establishment clause, the nature of Humanistic Education's threat to establishment clause values suggests that there are other, significantly less burdensome, means of inculcating morality. Humanistic Education's influence on private choice stems essentially from its moral relativism, methodological bias, and comprehensiveness. These factors combine to propel Humanistic Education beyond the pale of "secular" morality and into religious areas. By sharpening the religious profile of Humanistic Education, these factors also give Humanistic Education high political visibility.

Morality could be inculcated in a significantly less burdensome fashion. Instruction in morality, for public school purposes, does not need to explore the full range of moral issues. Nor does it need to pose the issues in a way that biases students against consulting external referents of truth. ${ }^{135}$

131. See D. PURPEL \& K. RYAN, supra note 46, at 9 (transmission of moral values in public schools is unavoidable, whether purposive or not); Arons \& Lawrence, supra note 13, at 97 (legal fiction that schooling can be morally neutral).

132. See Moskowitz, supra note 77, at 113-14 (most state legislatures have enacted statutes requiring public schools to inculcate morality).

133. See supra note 92 (discussing notion of secular morality).

134. See Stephens v. Bongart, 15 N.J. Mis. 80, 92, 189 A. 131, 137 (1937) ("[I]nstilling of worthy habits, attitudes, appreciations and skills is far more important than the mere imparting of subject-matter."); Moskowitz, supra note 77, at 107-14 (discussing history of moral instruction in public schools).

135. See Lockwood, supra note 55, at 168 (it is not necessary to embrace ethical relativism in avoiding pitfalls of authoritarianism). 
Finally, instruction in morality would engender less conflict with religious groups if it avoided controversial techniques such as group therapy or sensitivity training. Not only do these techniques rest upon specific theories of man's nature and the nature of morality, but they focus on the process of deriving moral values, and thus invite religious conflict.

If moral instruction were so limited and modified, the need to avoid presenting absolute values would be reduced. While, for example, beliefs about abortion vary greatly, there is a consensus of belief that stealing is wrong. Moreover, less attention would be directed to the source of belief if there were no dispute about the beliefs themselves. If necessary, however, instruction in morality could avoid presenting absolute or authoritarian models without biasing students against consulting them. Thus, restricting the scope of Humanistic Education and reducing its relativism would mitigate its conflict with religious interests without compromising the government's compelling interest in morality instruction in public schools. Adopting the less burdensome approach would also enhance political neutrality by reducing sources of political conflict over religious issues. 